\title{
Determination of Chromium in blood serum using Atomic Absorption Spectrophotometric (AAS)
}

\author{
https://doi.org/10.32792/utq/uti/vol11/2/8
}

\begin{abstract}
Mohammed T. Khathi, Abeer Q. Abdulwahab, Zainab M. Kareem
\end{abstract}

Chemistry dep., College of Science , Dhi- Qar University

E mail: dr.mohammedturki@yahoo.com

\begin{abstract}
:-
A new approach for the direct determination of chromium by Electrothermal Atomic Absorption spectrometry (ETAAS) is proposed, the method employs a $1.0 \mathrm{~cm}$ X $0.3 \mathrm{~cm}$ Tantalum metal coil placed in graphite tube. The experimental conditions for the determination of chromium via this method have been optimized. Pyrolysis and atomization curves are constructed using uncoated graphite tube without and with coil. The calibration curves were linear over the rang $10-50 \mathrm{ng} / \mathrm{ml}$ of chromium concentration, with relative standard deviation values, at $0.013,0.018$ and $0.024 \mu \mathrm{g} / \mathrm{ml}$. the accuracy and precision of the method was evaluated by determining recoveries percentage between (99.7-101) and standard deviation and using different concentrations of standard solutions of this method was applied successfully for the determination of chromium in human blood serum.
\end{abstract}

Key words : Blood serum, Chromium ,Electrothermal and Tantalum.

الخلاصة

تضمنت الدر اسة تطوير طريقة جديدة لتقدير عنصر الكروم مباثرة باستخدام مطيافية الامتصاص

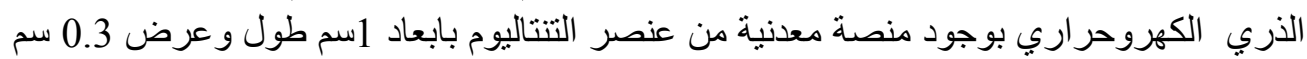
يتم وضعها داخل الفرن الكر افيتي بشكل ملف. 


\section{University of Thi-Qar Journal Vol.11 No.2 June 2016}

Web Site: https://jutq.utq.edu.iq/index.php/main Email: journal@jutq.utq.edu.iq

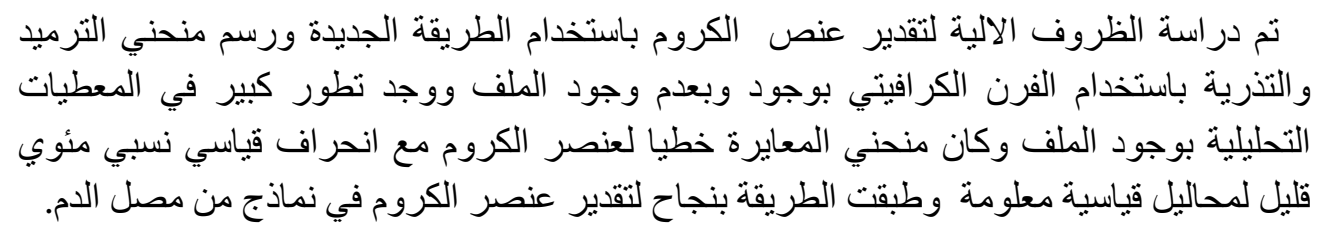

\section{Introduction:-}

Chromium recognized to be essential for human since the 1960. May have function in the control of glucose and lipid metabolism. Chromium deficiency leads to impaired lipid and glucose metabolism and results in high cholesterol levels. Although, the determination of chromium species $\mathrm{Cr}$ (III) and $\mathrm{Cr}(\mathrm{VI})$ is important, the total concentration of the element is very useful , especially if one form is determined and other form is calculated by differences $^{(1-6)}$.

Chromium exists in different oxidation states in groundwater, industrial waste water and soil.In the form $\mathrm{HCrO}_{4}{ }^{-} / \mathrm{Cr}_{2} \mathrm{O}_{7}{ }^{2-}\left(\mathrm{pH} \mathrm{1-6)}\right.$ or $\mathrm{CrO}_{4}{ }^{2-}(\mathrm{pH}>6)$. Is highly irritating and toxic to humans and animals ${ }^{(7-10)}$

Recently a number of methods using FAAS ${ }^{(1,7)}$, ICP-OES ${ }^{(3)}$, ETAAS ${ }^{(2,8,12)}$, OE and absorption spectroscopy ${ }^{(5)}$, CPE combination FAAS, ${ }^{(7,17)}$ AAS using chemically modified chloromethylated polystyrene - PAN Ion Exchange extraction solid- phase ${ }^{(8,9)}$, ICP-MS and ICP-AES ${ }^{(10,13,15)}$, ICP ${ }^{(11)}$, ICP-AAS (14) forked ETAAS ${ }^{(16)}$, Coil tungsten ${ }^{(16,18-21)}$, X- Ray Fluorescence $^{(22)}$ and tantalum second surface ${ }^{(23)}$

In this study a new atomization medium for Chromium determination via ETAAS was developed. It is simple constructed, available and gave accurate and precise results under mild heating cycle conditions in comparison with commercial uncoated graphite tube and no need for chemical modifiers to be used.

Materials and Methods:-

\section{Apparatus:-}




\section{University of Thi-Qar Journal Vol.11 No.2 June 2016}

Web Site: https://jutq.utq.edu.iq/index.php/main Email: journal@jutq.utq.edu.iq

Shimadzu model AA-6200 flame atomic absorption spectrophotometer and Graphite Furnace Flameless Atomic Absorption GFAAS-6200, Furnace Uncoated Shimadzu, Coil -tantalum length 50 centimeter, Centrifuge, micropipette.

\section{Chemicals:-}

A commercially available Stock solutions of each element studied were prepared by dissolving the appropriate mass of pure metals $(99.99 \%)$ in a slight excess of nitric acid and the solution then made up (Aldrich/ $1000 \mu \mathrm{g} / \mathrm{ml}$ in $\left.1 \% \mathrm{HNO}_{3}\right) \mathrm{Cr}\left(\right.$ as $\mathrm{K}_{2} \mathrm{CrO}_{4}$ FLXANAL)for each element and subsequent dilution is then carried out

to obtain calibration curve. Working solutions were freshly prepared by diluting aliquots of this solution with deionized water before use. Nitric acid, sulfuric acid and hydrochloric acid (Analytical grade, FLUKA) was used.

\section{Procedure:}

A series of chromium are standard solutions (10-50) $\mathrm{ng} / \mathrm{ml}$ prepared in $1 \% \mathrm{HNO} 3$ were injected in a uncoated graphite furnace in which a piece of tantalum metal $(1.0 \mathrm{cmX} 0.3 \mathrm{~cm})$ coil was inserted. The atomic absorption signal for each standard was measured after subjecting it to the heating cycle under optimum conditions.

In this study we use tantalum filament after we put coil on graphite furnace, a wire which has a length suitable (1.5 centimeter) and radius (1.2 $\mathrm{mm}$ ), and then put the furnace with the coil-tantalum in instrument (AAS), regular the furnace whereas the resonance radiation for element is pass without intercept with coil wire and complete regularly position to fall down droplet, it must be above wire coil completely and not on furnace wall or down the surface furnace show to fall down droplet by mirror constant on the basic of instrument to embrace using for this purpose.

This is done in three "stages for both elements:- 


\section{University of Thi-Qar Journal Vol.11 No.2 June 2016}

Web Site: https://jutq.utq.edu.iq/index.php/main Email: journal@jutq.utq.edu.iq

The first stage:- the temperature of atomization and ashing for both elements is found out by making atomization and ashing curves each individually.

The second stage:- finding the temperature of atomization and ashing elements after introducing single spiral in the graphite furnace and making atomization and ashing curves each individually.

The third stage:- finding the temperature of atomization and ashing for both elements after introducing couple spiral in the graphite furnace and making atomization and ashing curves each individually. The concentration $(0.03 \mu \mathrm{g} / \mathrm{ml})$ was used to find out the optimum temperature of ashing and atomization for both elements chromium within three stages.The ashing curve of manganese has been made when the furnace empty from the single spiral then the furnace contain double spiral, the atomization curve has been made by using the same method. The atomization and ashing curves of chromium element have been made by applied the previous methods.

These methods were applied on a number of human bloods in serum samples, and the levels of detection limit were good.

Sample collection and Serum preparation:

Blood samples were taken into plastic disposable from the controls subjects and placed in acid washed tubes. Serum were separated within two hours of collection and kept in refrigerator at freezing point until the day of analysis. All specimens were then thawed at ambient temperature, mixed thoroughly, centrifuged briefly to precipitate fibrin and then processed.

\section{Results and discussion}

Under optimum conditions graphite furnace atomic absorption spectroscopy method which was use above to study the effect of variable on the absorbance intensity that gave the optimum condition shown in tables for manganese and cobalt. 
Table(1). Instrumental conditions for a Shimadzu for four states of Element Chromium

\begin{tabular}{|c|c|c|c|c|}
\hline Element Chromium & $\begin{array}{c}\text { Drying } \\
\text { Temp. }\left(\mathbf{C}^{\circ}\right)\end{array}$ & $\begin{array}{c}\text { Ashing } \\
\text { Temp. }\left(\mathbf{C}^{\circ}\right)\end{array}$ & $\begin{array}{c}\text { Atomize } \\
\text { Temp. }\left(C^{\circ}\right)\end{array}$ & $\begin{array}{c}\text { Cleaning } \\
\text { Temp. }\left(\mathbf{C}^{\circ}\right)\end{array}$ \\
\hline Uncoated Without Coil & 100 & 1100 & 2400 & 2600 \\
\hline Coated furnace & 100 & 1000 & 2300 & 2500 \\
\hline $\begin{array}{l}\text { Uncoated \& single coil } \\
\text { Tantalum }\end{array}$ & 100 & 1000 & 2300 & 2500 \\
\hline uncoated\&platform Ta & 100 & 900 & 2200 & 1800 \\
\hline
\end{tabular}

Figures a calibration graph for chromium has been obtained for $10 \mu 1$ volume injection for several concentrations. Figures show the absorbance measurements of a series of standard solutions prepared in different concentrations and the triplicate

mode for each set of standard, in this figure the absorbance measurements refer very clearly to the good reproducibility which has been obtained indicating that the method of preparing the standard solution are done in good methodology. It can be seen from the results obtained that improved sensitivity is achieved with coil Ta compared to another atomization. 


\section{University of Thi-Qar Journal Vol.11 No.2 June 2016}

Web Site: https://jutq.utq.edu.iq/index.php/main Email: journal@jutq.utq.edu.iq

The statistical treatments for calibration graphs are summarized in table (2)

Table(2): Analytical values of statistical treatments for the chromium

\begin{tabular}{|c|c|c|c|c|}
\hline $\begin{array}{c}\text { Parameters } \\
(\mathbf{C r})\end{array}$ & $\begin{array}{c}\text { Without } \\
\text { coil-Ta }\end{array}$ & $\begin{array}{c}\text { Coated } \\
\text { furnace }\end{array}$ & $\begin{array}{c}\text { With single } \\
\text { Coil - Ta }\end{array}$ & $\begin{array}{c}\text { With } \\
\text { platform-Ta }\end{array}$ \\
\hline $\begin{array}{c}\text { Correlation } \\
\text { coefficient }\end{array}$ & 0.9994 & 0.9997 & 0.9999 & 0.9999 \\
\hline $\begin{array}{c}\text { Regression } \\
\text { equation }\end{array}$ & $\begin{array}{c}63.766 \mathrm{X}- \\
0.0111\end{array}$ & $\begin{array}{c}76.484 \mathrm{X}+ \\
0.0008\end{array}$ & $85.697 \mathrm{X}+0.001$ & $\begin{array}{c}93.135 \mathrm{X}- \\
0.0016\end{array}$ \\
\hline $\begin{array}{c}\text { Slope }(\mathrm{ml} / \mu \mathrm{g}- \\
\left.{ }^{1}\right), \mathrm{b}\end{array}$ & 63.766 & 76.484 & 85.697 & 93.135 \\
\hline $\begin{array}{c}\text { Intercept a } \\
\text { Standard } \\
\text { reviation for }\end{array}$ & 0.00263296 & 0.00760698 & 0.001376 & 0.0037228 \\
\hline $\begin{array}{c}\text { Limit of } \\
\text { Detection } \\
(\mu \mathrm{g} / \mathrm{ml})\end{array}$ & 0.0000507 & 0.00002104 & $1.2797 \mathrm{X} 10^{-5}$ & 0.0000117869 \\
\hline $\begin{array}{c}\text { Limit } \\
\text { quantification } \\
(\mu \mathrm{g} / \mathrm{ml})\end{array}$ & 0.002633 & 0.000994 & $1.606 \mathrm{X} 10^{-3}$ & 0.00039973 \\
\hline \begin{tabular}{c} 
Sensitivity \\
\hline
\end{tabular} & 0.00000664 & 0.0000046684 & $4.112 \mathrm{X} 10^{-6}$ & 0.000003447 \\
\hline
\end{tabular}


The accuracy and precision of the determination (Chromium) was studied depending upon the value of the relative error (E \%), Recovery (Rec $\%)$ and Relative standard deviation (RSD \%) respectively.

For five replicate measurements of each of concentration were done and the average value were used, the results were listed in table (3) which show good accuracy and precision in aqueous solutions and in blood sera samples.

Table(3): Accuracy \& precision of Selenium

\begin{tabular}{|c|c|c|c|c|c|}
\hline \multirow{2}{*}{ Chromium } & \multicolumn{2}{|c|}{ Conc. $\mu$ g/ml } & \multirow{2}{*}{ E\% } & Rec\% & RSD\% \\
\cline { 2 - 5 } & Present & Found & & & \\
\hline Without coil & 0.006 & 0.0059 & -1.667 & 98.333 & 0.173 \\
\hline $\begin{array}{c}\text { Coated } \\
\text { furnace }\end{array}$ & 0.006 & 0.00602 & +0.333 & 100.333 & 0.165 \\
\hline single coil Ta & 0.006 & 0.00609 & +1.5 & 101.5 & 0.107 \\
\hline Platform- Ta & 0.006 & 0.00612 & +2 & 102 & 0.098 \\
\hline
\end{tabular}

Table(4). Accuracy \& precision of Chromium in serum samples

\begin{tabular}{|c|c|c|c|c|c|c|}
\hline $\begin{array}{c}\text { Samples } \\
\text { with } \\
\text { coated } \\
\text { furnace }\end{array}$ & \multicolumn{3}{|c|}{$\begin{array}{c}\text { Serum Chromium Conc. } \\
\mu \mathrm{g} / \mathrm{ml}\end{array}$} & \multirow{2}{*}{ Error \% } & Rec. \% & RSD\% \\
\cline { 2 - 6 } & Present & Added & Found & & & \\
\hline 1. & 0.026 & 0.001 & 0.0262 & 0.769 & 100.769 & 0.121 \\
\hline 2. & 0.032 & 0.002 & 0.0323 & 0.938 & 100.938 & 0.1 \\
\hline
\end{tabular}


University of Thi-Qar Journal Vol.11 No.2 June 2016

Web Site: https://jutq.utq.edu.iq/index.php/main Email: journal@jutq.utq.edu.iq

3.

0.048

0.003

0.0485

0.833

100.833

0.06711

Table(5). Accuracy \& Precision of Chromium in serum samples

\begin{tabular}{|c|c|c|c|c|c|c|}
\hline \multirow{2}{*}{$\begin{array}{l}\text { Samples \& } \\
\text { single coil - } \\
\text { Tantalum }\end{array}$} & \multicolumn{3}{|c|}{$\begin{array}{c}\text { Serum Chromium Conc. } \\
\mu \mathrm{g} / \mathrm{ml}\end{array}$} & \multirow{2}{*}{ Error \% } & \multirow{2}{*}{ Rec. \% } & \multirow{2}{*}{ RSD\% } \\
\cline { 2 - 6 } & Present & Added & Found & & & \\
\hline 1. & 0.021 & 0.001 & 0.0213 & 1.428 & 101.428 & 0.165 \\
\hline 2. & 0.032 & 0.002 & 0.0324 & 1.25 & 101.25 & 0.11 \\
\hline 3. & 0.048 & 0.003 & 0.0485 & 1.46 & 101.46 & 0.06711 \\
\hline
\end{tabular}

Table(6). Accuracy \& precision of Chromium in Serum samples

\begin{tabular}{|c|c|c|c|c|c|c|}
\hline \multirow{2}{*}{$\begin{array}{l}\text { Samples \& } \\
\text { platform } \\
\text { Tantalum }\end{array}$} & \multicolumn{3}{|c|}{$\begin{array}{c}\text { Serum Chromium Conc. } \\
\mu \mathrm{g} / \mathrm{ml}\end{array}$} & \multirow{2}{*}{ Error \% } & \multirow{2}{*}{ Rec. \% } & \multirow{2}{*}{ RSD\% } \\
\cline { 2 - 5 } & Present & Added & Found & & & \\
\hline 1. & 0.021 & 0.001 & 0.0214 & +1.9 & 101.9 & 0.175 \\
\hline 2. & 0.032 & 0.002 & 0.0327 & 2.2 & 102.2 & 0.168 \\
\hline 3. & 0.048 & 0.003 & 0.0489 & +1.875 & 101.875 & 0.112 \\
\hline
\end{tabular}


University of Thi-Qar Journal Vol.11 No.2 June 2016

Web Site: https://jutq.utq.edu.iq/index.php/main Email: journal@jutq.utq.edu.iq

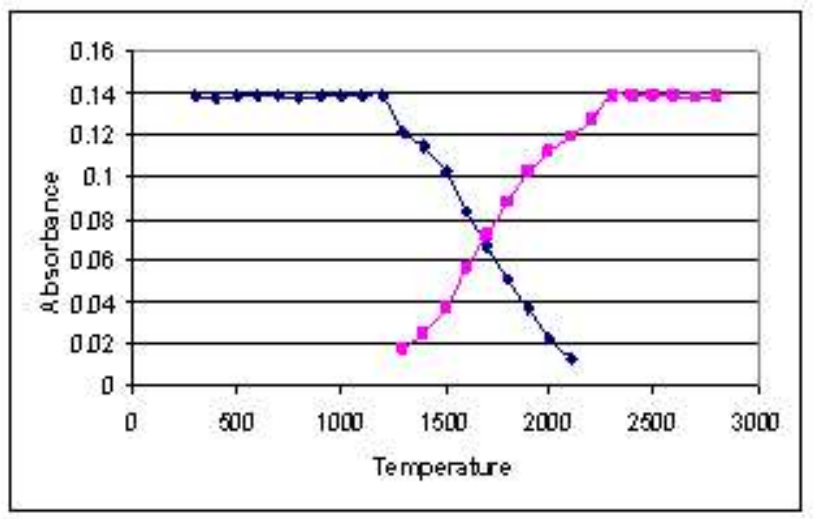

Figure (1) Ashing Curves and Atomization Curves for uncoated GFAAS chromium

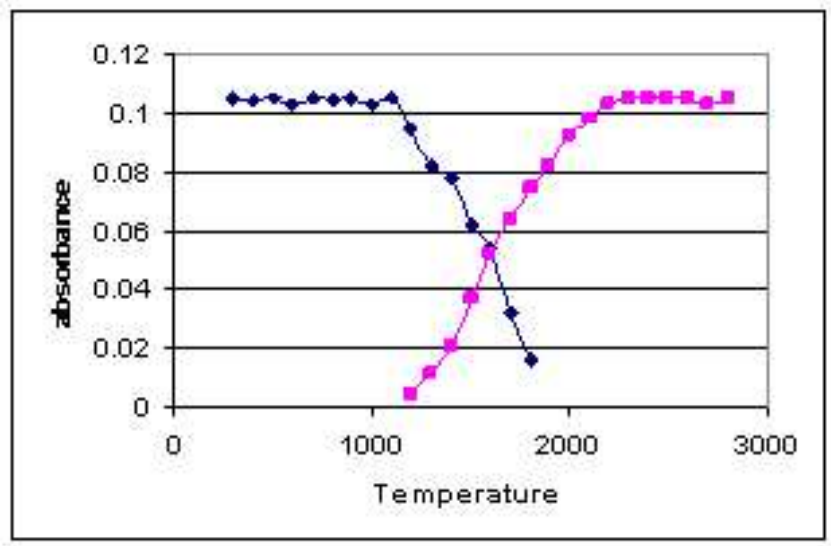

Figure (2) Ashing Curves and Atomization Curves for coated GFAAS chromium 
University of Thi-Qar Journal Vol.11 No.2 June 2016

Web Site: https://jutq.utq.edu.iq/index.php/main Email: journal@jutq.utq.edu.iq

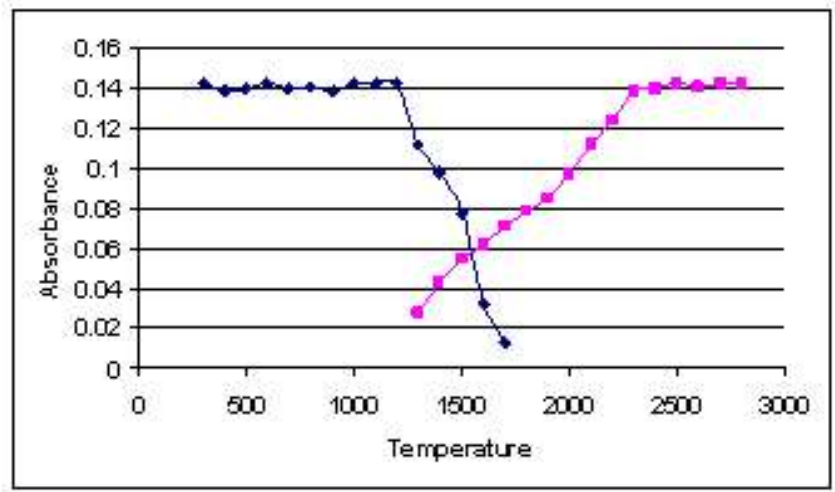

Figure (3) Ashing Curve and Atomization Curve for Uncoated GFAAS with single coil of Chromium

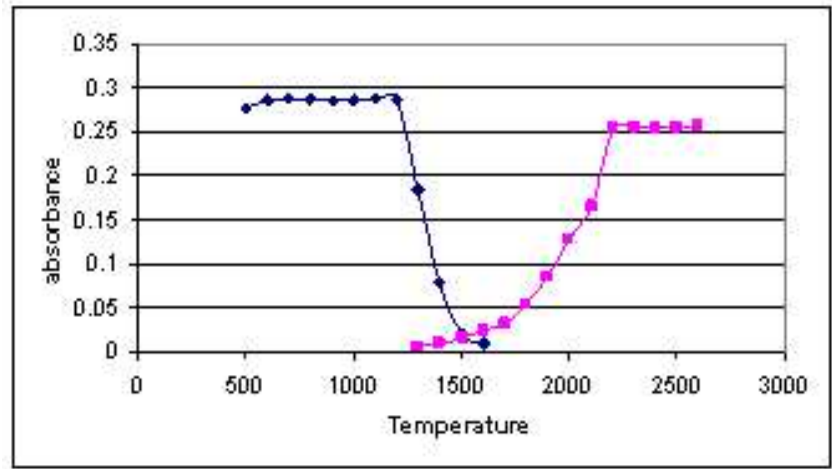

Figure (4) Ashing Curve and Atomization Curve for uncoated GFAAS with single coil tantalum of Chromium 


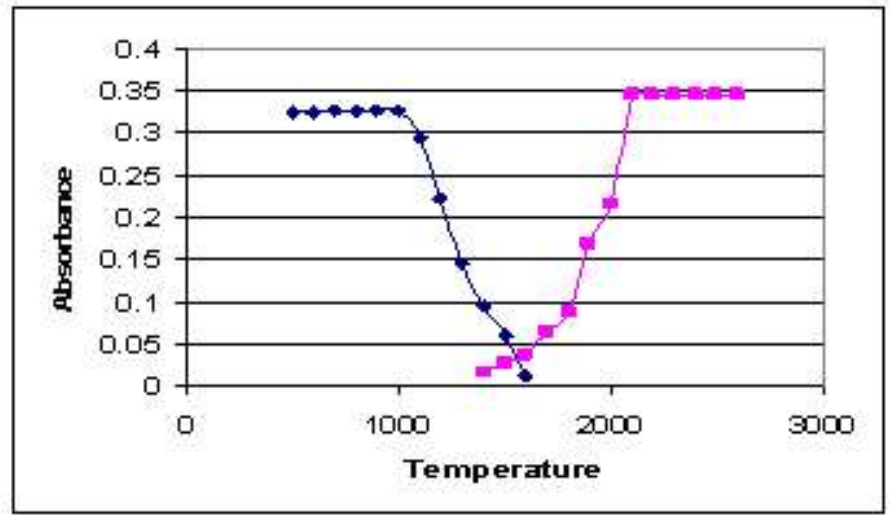

Figure (5) Ashing Curve Atomization of uncoated with platform Tantalum of Chromium

\section{References:-}

1- Carmen Camara and Philippe Quevauviller " Assessment of methods currently used for the determination of chromium and selenium species in solutions", trends in analytical chemistry, vol.19, No. 2+3, 189-194, 2000.

2- Fariba Tadayon and sahar Rajabi Nia " determination of toxic and essential elements in the scalp hair of patients with type 2 Diabetes" Academic Research international, vol.2, No.3, 11-16,2012.

3- Mohammad Reza Ganjali'Novel method for fast enrichment and monitoring of hexavalent and trivalent chromium at the ppt level with modified silica mcm-41 and its determination by inductively coupled plasma optical emission spectrometry, Quim. Nova, vol. 29, No.3, 440-443, 2006.

4- Artimon M., Tanase GH.I, Pele M, and Vesile G., "Aspect concerning validation of a method for chromium content determination in Romanian wines by ETAAS after microwave mineralization" Romanian Biotechnological letters, vol.13, No. 6, 4022-4029,2008. 


\section{University of Thi-Qar Journal Vol.11 No.2 June 2016}

Web Site: https://jutq.utq.edu.iq/index.php/main Email: journal@jutq.utq.edu.iq

5- Gordon F. Kirkbright " some recent studies in optical Emission and Absorption spectroscopy for trace Analysis", pure and Appl. Chem ,Vol.54, No.4, p.769-786,1982

6- Madhuchandra LM, Nanda N, Jayaveera KN, "determination of chromium in different water samples using cloud point Extraction (CPE) coupled with flame atomic Absorption spectrometry ((FAAS), RJPBCS, vol.2, No.3, 1119-1128, 2011.

7- I.M.M. Kenawy, M.A.H. Hafez, M. A. Akl And R. R. Lashein " determination by AAS of some trace heavy metals Ions in some natural and Biological samples after their pre-concentration using newly chemically modified chloromethylated polystyrene- PAN Ion -Exchanger. Analytical Sciences, 2000, v.16, 493-500

8- Gouhui Zhu and Shunxi Li " separation and pre-concentration of chromium species by selective absorption on Lemna minor and determination by slurry atomization electrothermal atomic absorption spectrometry “ Analyst, 126, 1453-1455, 2001.

9- Tetsuo Inui, Kazuhiro Fujita, Masaru Kitaro and Tashihiro Nakamura, " determination of $\mathrm{Cr}$ (III) and Cr (VI) at sub - ppb levels in water with solid - phase extraction/ metal furnace atomic absorption spectrometry. Analytical Sciences 2010.26

10- Takashi Sumlda, Tetsuya Nakazato, Hiroaki Tao, Mitsuko Oshima and Shoji motomizn" on- line preconcentration system using mini columns packed with a chelating resin for the characterization of seasonal variations of trace elements in sea water by ICP- Mass and ICP- AES" Analytical Sciences, 2006, V. 22, 1163-1168

11- Kyue- Hyurg Lee, Mistsuko Oshima, Toshio Takayanagi and Shoji Motomizu " stimultaneous determination of trace elements in river water samples by ICP- MS in combination with a discrete microsamples technique after enrichment with a chitosan - based chelating resin. Analytical Sciences 2000, v.16, 731-738. 


\section{University of Thi-Qar Journal Vol.11 No.2 June 2016}

Web Site: https://jutq.utq.edu.iq/index.php/main Email: journal@jutq.utq.edu.iq

12- Monteiro M.I.C. and NeumannR., "determination of chromium by electrothermal atomic absorption spectrometry in waters using a forked platform and co-injection of $\mathrm{Mg}$ as chemical modifier", Analytica chimica Acta, 428, 265-278,2001.

13- Boevski IV., Daskalova N. and Havezova I."determination of barium, chromium cadmium manganese, lead and zinc in atmospheric particulate matter by inductively coupled plasma atomic emission spectrometry (ICP-AES), Spectrochimica Acta part B 55, 1643-1657, 2000 .

14- C.F. Wang, C.J. Chin and Pen-Chi Chiang " Multielement Analysis of suspended particulates collected with a Beta- Guage monitoring system by ICP- atomic Emission spectrometry and mass spectrometry" Analytical Sciences, 1998, V.14, 763- 768.

15-Tomoki Yabutani, Yumi Nakamoto and Ryoji Yamanouchi " Multielemental Characterization of Airbone particulate matter collected in Bucharest and Tokushima by Inductively coupled plasma mass spectrometry and Inductively coupled plasma Atomic Emission spectrometry" Analytical Sciences, 2010, V. 26, 395-400.

16- Rosa Moreno Camero and Jose Alvarado " determination of carbideforming metals, chromium and barium by graphite furnace atomic absorption spectrometry using a tungsten coil platform" spectrochimica Acta part B 55, 875-881, 2000

17- Ojeka E.O. and Achi E.G., "determination of trace elements in vegetable samples using the slurry method for flame AAS, Atomic spectroscopy, vol.26, No.5, 187-190,2005.

18- Jiyan Gu, Summer Hanna and Bradley T. Jones " A portable tungsten coil atomic emission spectrometer for the simultaneous determination of metals in water and soil samples" Analytical Sciences, 2011, V.27, 523- 527. 
19- A. Jennifer Rust, A. Joaquim Nobrega, P. Clifton Calloway and T. Jones Bradley "Tungsten coil atomic Emission spectrometry" spectrochimica Acta Part B. 2006,61, 225- 229.

20-M. Knochen, E. Sarltsky and I. Dol "Evaluation of a modified spectrometer for electrothermal atomic absorption spectrometry with tungsten coils, determination of chromium" Quim. Anal., 1996, 15, 184-190.

21-C.G. Bruhn, F.E. Ambiado, H. J. Cid, R. Woerner, J. Tapia and R. Garcia, " Analytical evaluation of atungsten coil Atomizer for cadmium, lead , chromium, ManganeseNickel and Cobalt determination by electrothermal atomic absorption spectrometry" Anal. Chim. Acta, 1995, 306, 183-192.

22-Hagen Stosnach " Environmental trace element analysis using a Bench top total Reflection X- Ray Fluorescence Spectrometer " Analytical Science 2005, v. 21, 873- 876.

23-Thomas M. Rettberg and James A. Holocombe" A temperature controlled, Tantalum second surface for graphite furnace atomization" spectrochimica Acta, vol.39B Nos2/3, 249-260,1984 